\title{
RAISING OF MAHOGANY (Swietenia mahagoni L.) SEEDLINGS TO COMBAT CLIMATE CHANGE AS INFLUENCED BY ORGANIC MANURES AND CHEMICAL FERTILIZERS
}

\author{
Mitu, Sk. R. I., R. Rifhat, I. Jahanara, H. B. Murshed and M. K. Rahman \\ Department of Soil, Water and Environment, University of Dhaka, Dhaka-1000, Bangladesh
}

\begin{abstract}
Effects of various organic manures on the growth, performance and biomass production of Mahogany seedlings, an experiment was carried out in the net house of the Department of Soil, Water and Environment, University of Dhaka. Nine types of manures, viz. Kazi, ACI, Payel, BGF-1, Mazim, SK, Supermill, Sebok, Sufola organic manures were used separately at the rate of 12 ton/ha. Another dose of NPK inorganic fertilizer was used at the rate of $5 \mathrm{~kg} / \mathrm{ha} \mathrm{N}, 3 \mathrm{~kg} / \mathrm{ha} \mathrm{P}, 3 \mathrm{~kg} / \mathrm{ha} \mathrm{K}$ respectively. Height, leaf area, and fresh and dry weights of leaf varied significantly $(\mathrm{p} \leq 0.5)$ and increased with time. Maximum leaf number $(41.33$ no./plant $)$ and branch (6.33 no./plant) was found in Payel compost but maximum $\mathrm{N}$ concentration (2\%) in leaf was obtained in Sebok treatment. Highest plant height $(48.33 \mathrm{~cm})$, leaf area $\left(204.766 \mathrm{~cm}^{2} /\right.$ plant $)$, girth $(3.067 \mathrm{~cm} / \mathrm{plant})$, fresh weight $(37.79 \mathrm{~g} / \mathrm{plant})$, dry weight $(9.16 \mathrm{~g} / \mathrm{plant})$, and length of petiole $(6.33 \mathrm{~cm})$ were recorded in Supermill treatment at harvest. Results showed that the overall best growth performance of seedlings was achieved in Supermill compost.
\end{abstract}

Key words: Biomass, Chemical fertilizer, Growth, Organic manure, Supermill, Swietenia mahagoni L.

\section{INTRODUCTION}

Mahogany is a well-known evergreen plant of Meliaceae family. It was brought into some Asian countries to Bolivia from Caribbean, Mexico and Southern to Central America. Three species based of geographically separated are known as Swietenia mahagoni (L.) Jacq (West Indian mahagoni), Swietenia humilis Zucc (Pacific Coast mahagoni), and Swietenia macrophylla King (Honduran mahagoni) (Orwa et al. 2009). Mahogany (other name American mahagoni) is a briefly deciduous tree commonly found in Southeastern part of North America. It is an afforestational plant which can be sustainable to every climatic region. It takes 25 years to be matured for a plant. And a mature tree can be 40 to 60 feet high on average, and in a maximum 75 feet high.

Organic manures have been shown to help preserve natural resources and reduce degradation of ecosystem (Mader et al. 2002) and also improve the soil nutritional status as well as influence other soil properties. It is also a source of food for soil microorganisms. It increases the activity of microbes which in turn helps to convert unavailable plant nutrients into available form. Organic manures release nitrogen slowly, and leaching and volatilization losses are also very less as compared to inorganic fertilizers. The continuous chemical fertilizer use deteriorates crop while organic manures improve these properties (Watson et al. 2002).

Application of organic manures singly or in combination with either other organic fertilizers or chemical fertilizers have been proved effective to enhance growth and yield of various plants like Sunflower, Soybean, Okra, Gynura, Ground nut (Alauddin et al. 2019). The increasing cost of chemical fertilizers and their harmful effects on the soil health are also an important consideration for the use of organic nutrients (Patel et al. 2005). Chemical fertilizers combined with organic manures result in reduction of soil nitrate content (Yang et al. 2005), increase of cation exchange capacity and soil organic matter, improvement of soil properties, and increase of crop yield.

Mahogany is used commonly for high-quality furniture, joinery, musical instruments, etc. It is very much expensive for its timber quality, color, firmness and durability. Mahogany is used primarily as wood for its rapid growth and excellent timber quality (Hossain 2015) though often used as a shade tree. The seed oil has a value of pesticide. It is examined that if there is a mahogany tree beside any crop 
field, crops are relatively safe from pest's attack. Plants provide great alternatives to manage diabetes. It is used in many developing countries with natural diversity resources. Mahogany is a medicinal plant throughout the Caribbean regions. The bark is considered as astringent and is taken orally as a decoction for diarrhea, as a source of vitamins and iron, and as a medicine to induce hemorrhage. When the bark is steeped to red liquor, it is taken to clear blood, increase appetite, and restore strength in case of tuberculosis (Hossain 2015).

The Government of Bangladesh has given top priority on tree planting in the degraded forests to regreen them through a benefit-sharing mechanism with local people's active participation. Collaboration among Government organizations, NGOs, local government bodies and people in general is essential to move forward this movement to a success (Hossain 2015). Along with coastal plantations in the districts of Barguna, Patuakhali, Bhola, Noakhali, Chattogram and Cox's Bazar Mahogany seedlings could be planted on the slope of the both sides of the dykes which will probably provide protection against natural calamities like tidal surges and cyclones, and absorb huge quantity of carbon dioxide from the atmosphere.

In nursery practices, organic manures can be used to produce healthy, strong green and leafy Mahogany seedlings and inorganic fertilizers of NPK should be avoided especially at Barishal, Jhalokathi and Pirojpur locations. A scanty information is available on raising of Mahogany seedlings and plantations under organic farming system in Bangladesh.

The objective of present experiment was to evaluate the effect of organic manure and NPK fertilizers on growth and yield performance of Mahogany (Swietenia mahagoni L.) grown in pot experiment at the premise of Department of Soil, Water and Environment, University of Dhaka.

\section{Soil sample collection}

\section{MATERIAL AND METHODS}

Soil sample (0 to $15 \mathrm{~cm}$ depth) was collected from Dhaka. The sample was air-dried, ground and sieved through $2 \mathrm{~mm}$ sieve. The soil had a pH of $6.86(1: 2.5 \mathrm{w} / \mathrm{v} \mathrm{H} 2 \mathrm{O})$, organic carbon $0.26 \%$ (Wet oxidation method, Walkley and Black 1934), available nitrogen $24 \mathrm{mg} / \mathrm{kg}$ (Kjeldahl extraction, Marr and Cresser 1983), available phosphorus $6 \mathrm{mg} / \mathrm{kg}$ (Murphy and Riley 1962), sand 3.77\%, silt $68.23 \%$ and clay $28.00 \%$, textural class- silt loam (Bouyoucos 1962), and water holding capacity was 32\%. Leaf nitrogen is determined by (Cresser and Parson 1979) method.

\section{Leaf nitrogen determination}

$0.1 \mathrm{~g}$ dried and ground sample was taken and $5 \mathrm{ml}$ conc. $\mathrm{H}_{2} \mathrm{SO}_{4}$ and $2 \mathrm{ml} 4 \%$ (v/v) of $\mathrm{HClO}_{4}(62 \%)$ was added with the sample. The digest was cooled and diluted to $100 \mathrm{ml}$ with deionized water (Cresser and Parson 1979). $10 \mathrm{ml}$ prepared sample was taken twice and after adding $10 \mathrm{ml} 40 \% \mathrm{NaOH}$ with $10 \mathrm{ml} 2 \%$ Boric acid was titrated with $0.02 \mathrm{M} \mathrm{HCl}$.

\section{Pot Experiment}

A pot experiment (Fig. 1) was carried out in the net house of the Department of Soil, Water and Environment, University of Dhaka. Seven kilograms of soil were taken per plastic pot (height $24 \mathrm{~cm}$ and diameter $25 \mathrm{~cm}$ ). Nine types of organic manures manufactured by different companies were collected from the local market. The manures were Kazi and kazi, ACI, Payel, BGF-1, Mazim, SK, Sufola, Sebok and Supermill compost along with a separate dose of NPK at the rate of $5 \mathrm{~kg} / \mathrm{ha}, 3 \mathrm{~kg} / \mathrm{ha}$ and $3 \mathrm{~kg} / \mathrm{ha}$ respectively. The organic manures were properly mixed separately at the rate of 12 ton/ha with soil. Eleven treatments with three replications were used. Seeds of $S$. mahagoni were collected from Horticulture Centre, Asadgate, Dhaka. Three seeds were sowed per pot for germination and after two 
weeks seedlings were transported to compost mixed soils. The pots were watered thrice a week in the morning. The height of the plant, the numbers of leaves and leaf area were measured at 15 days interval up to 105 days.

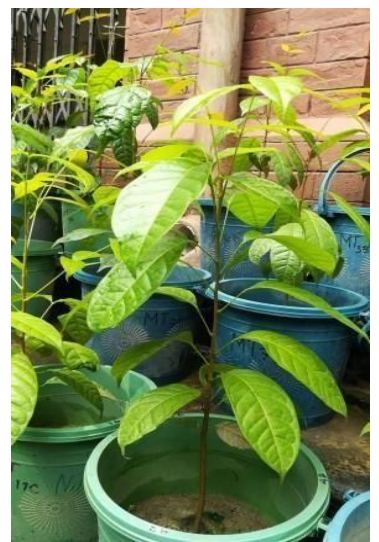

Fig. 1. Mahogany seedlings grown in Supermill at harvest.

\section{Harvesting}

The plants were harvested as leaf, stem, root, washed with tap water and finally with distilled water, and wrapped with tissue paper. Immediately after the harvest, fresh weight of leaf, stem and root were taken and then air-dried in the room temperature and finally oven-dried at $65^{\circ} \mathrm{C}$ in the laboratory for 48 hours. The dry weight of the samples was recorded and the samples were ground with a mechanical grinder and stored in the polythene bags for further chemical analysis.

Statistical analysis: Analysis of variance along with mean differences was performed using Minitab 2019.

\section{RESULTS AND DISCUSSION}

Plant growth was assessed in terms of plant height (Table 1), leaf number (Table 2), leaf area (Table 3 ), girth and branch number (Table 4), length of petiole (Table 5) and biomass production as leaf, stem and root (Table 6). Height values of 0,15, 30, 45, 60, 75, 90 and 105 days increased significantly after the germination $(\mathrm{p} \leq 0.5)$ (Table 1$)$. However, the highest plant height $(48.33 \mathrm{~cm})$ was observed in the organic treatment Supermill after 105 days of growth.

Table 1. Effects of organic manures and NPK fertilizers on the height (cm) of Swietenia mahagoni L.

\begin{tabular}{|c|c|c|c|c|c|c|c|}
\hline \multirow[t]{2}{*}{ Treatments } & \multicolumn{7}{|c|}{ Days after transplanting } \\
\hline & $15 d$ & 30d & $45 d$ & 60d & $75 d$ & 90d & 105d \\
\hline Control (-OM\&- NPK) & 21.00 & 25.00 & 33.33 & 32.10 & 36.67 & 40.50 & 43.00 \\
\hline Kazi and kazi (12 ton $\left.\mathrm{ha}^{-1}\right)$ & 22.03 & 24.00 & 24.67 & 26.33 & 30.17 & 33.00 & 37.50 \\
\hline $\mathrm{ACI}\left(12\right.$ ton $\left.\mathrm{ha}^{-1}\right)$ & 23.33 & 26.67 & 29.00 & 32.33 & 33.83 & 36.17 & 39.17 \\
\hline Payel (12 ton $\left.\mathrm{ha}^{-1}\right)$ & 20.33 & 23.00 & 24.17 & 28.00 & 31.67 & 36.33 & 42.67 \\
\hline BGF-1(12 ton ha $\left.{ }^{-1}\right)$ & 18.00 & 22.17 & 23.67 & 26.57 & 32.17 & 32.67 & 26.33 \\
\hline $\operatorname{Mazim}\left(12\right.$ ton $\left.\mathrm{ha}^{-1}\right)$ & 19.73 & 24.17 & 26.67 & 31.33 & 33.33 & 39.33 & 42.67 \\
\hline SK $\left(12\right.$ ton $\left.\mathrm{ha}^{-1}\right)$ & 20.17 & 23.33 & 26.67 & 31.67 & 36.00 & 40.50 & 43.67 \\
\hline Supermill $\left(12\right.$ ton $\left.\mathrm{ha}^{-1}\right)$ & 24.33 & 26.67 & 29.67 & 23.17 & 37.67 & 44.17 & 48.33 \\
\hline Sebok $\left(12\right.$ ton $\left.\mathrm{ha}^{-1}\right)$ & 20.00 & 24.00 & 27.50 & 30.50 & 35.33 & 35.33 & 37.83 \\
\hline Sufola (12 on ha $\left.{ }^{-1}\right)$ & 18.00 & 19.33 & 21.67 & 25.67 & 32.17 & 33.67 & 33.50 \\
\hline $\mathrm{N}_{5} \mathrm{P}_{3} \mathrm{~K}_{3} \mathrm{~kg} \mathrm{ha}^{-1}$ & 17.75 & 19.67 & 21.67 & 23.67 & 28.17 & 25.50 & 45.33 \\
\hline LSD at $5 \%$ level & 3.05 & 3.71 & 0.61 & NS & 3.05 & 4.31 & 1.93 \\
\hline
\end{tabular}


The application of organic fertilizer is based on crop NPK requirements, was likely to provide other nutrients required by the crops. The leaf number increased up to 105 days (Table 2). The highest values were recorded in treatment: Payel. The leaf numbers at 60, 75, 90 and 105 days increased significantly $(\mathrm{p} \leq 0.5)$ (Table 2$)$. The minimum values of leaf number were observed in the treatment: SK.

Table 2. Effects of organic manures and NPK fertilizers on the leaf number/plant of Swietenia mahagoni L.

\begin{tabular}{|c|c|c|c|c|c|c|c|}
\hline \multirow[t]{2}{*}{ Treatments } & \multicolumn{7}{|c|}{ Days after transplanting } \\
\hline & 15d & 30d & 45d & 60d & $75 d$ & 90d & 105d \\
\hline Control (-OM\&- NPK) & 9.33 & 10.67 & 14.33 & 18.67 & 24.33 & 29.00 & 32.33 \\
\hline Kazi and kazi $\left(12\right.$ ton $\left.\mathrm{ha}^{-1}\right)$ & 8.33 & 9.00 & 11.00 & 11.67 & 13.67 & 18.33 & 25.67 \\
\hline ACI $\left(12\right.$ ton $\left.h^{-1}\right)$ & 8.33 & 10.00 & 12.00 & 13.33 & 16.67 & 17.67 & 25.00 \\
\hline Payel $\left(12\right.$ ton $\left.\mathrm{ha}^{-1}\right)$ & 9.33 & 10.00 & 12.00 & 15.67 & 21.67 & 28.33 & 41.33 \\
\hline BGF-1(12 ton $\left.\mathrm{ha}^{-1}\right)$ & 7.33 & 10.00 & 11.10 & 13.67 & 20.33 & 20.00 & 25.00 \\
\hline $\operatorname{Mazim}\left(12\right.$ ton $\left.\mathrm{ha}^{-1}\right)$ & 9.00 & 11.00 & 11.67 & 16.00 & 18.03 & 25.33 & 24.33 \\
\hline SK $\left(12\right.$ ton $\left.h^{-1}\right)$ & 8.33 & 10.00 & 13.33 & 14.67 & 16.33 & 20.67 & 21.00 \\
\hline Sufola $\left(12\right.$ ton $\left.\mathrm{ha}^{-1}\right)$ & 10.00 & 10.67 & 15.00 & 19.67 & 24.67 & 34.00 & 35.00 \\
\hline Sebok (12 ton $\left.\mathrm{ha}^{-1}\right)$ & 8.00 & 10.00 & 11.33 & 13.00 & 17.00 & 20.67 & 23.00 \\
\hline Supermill $\left(12\right.$ ton $\left.\mathrm{ha}^{-1}\right)$ & 7.00 & 7.33 & 11.00 & 13.33 & 20.00 & 19.00 & 23.67 \\
\hline $\mathrm{N}_{5} \mathrm{P}_{3} \mathrm{~K}_{3} \mathrm{~kg} \mathrm{ha}^{-1}$ & 6.67 & 9.67 & 10.67 & 12.00 & 16.00 & 17.67 & 29.67 \\
\hline LSD at $5 \%$ level & 1.95 & 2.66 & 3.48 & 5.26 & NS & 3.56 & 1.93 \\
\hline
\end{tabular}

The results of the leaf area measurement are presented in Table 3. Leaf area was maximum (204.77 $\mathrm{cm}^{2} /$ plant) in Supermill. The leaf area continuously increased up to 105 days of growth. The second highest value was obtained in Payel $\left(184.68 \mathrm{~cm}^{2} /\right.$ plant). Leaf area differs significantly due to organic manures.

The values of plant height (Table 1), number of leaf (Table 2) and leaf area (Table 3) were recorded higher in the control treatment than in few other treatments. Probably the manufacturers did not maintain the standard grade for manufacturing that organic manure that is why the availability of nutrients in the composts collected from the local market is comparatively low.

Table 3. Effects of organic manures and NPK fertilizers on the leaf area $\left(\mathrm{cm}^{2} / \mathrm{plant}\right)$ of Swietenia mahagoni L.

\begin{tabular}{|c|c|c|c|c|c|c|c|}
\hline \multirow[t]{2}{*}{ Treatments } & \multicolumn{7}{|c|}{ Days after transplanting } \\
\hline & $15 d$ & 30d & $45 d$ & 60d & $75 d$ & 90d & $105 d$ \\
\hline Control (-OM\&- NPK) & 66.33 & 77.93 & 100.98 & 127.51 & 115.89 & 123.39 & 125.64 \\
\hline Kazi and kazi (12 ton $\left.\mathrm{ha}^{-1}\right)$ & 85.44 & 90.72 & 101.80 & 131.67 & 144.18 & 144.18 & 150.86 \\
\hline ACI $\left(12\right.$ ton $\left.\mathrm{ha}^{-1}\right)$ & 51.96 & 65.71 & 97.67 & 117.14 & 126.35 & 126.35 & 124.10 \\
\hline Payel (12 ton $\left.\mathrm{ha}^{-1}\right)$ & 87.88 & 89.50 & 133.14 & 136.10 & 154.00 & 198.67 & 184.67 \\
\hline BGF-1(12 ton ha $\left.{ }^{-1}\right)$ & 60.84 & 107.20 & 109.35 & 103.48 & 110.50 & 107.61 & 116.72 \\
\hline $\operatorname{Mazim}\left(12\right.$ ton $\left.\mathrm{ha}^{-1}\right)$ & 67.76 & 89.12 & 90.61 & 108.80 & 169.35 & 161.26 & 166.20 \\
\hline SK (12 ton $\left.\mathrm{ha}^{-1}\right)$ & 79.69 & 87.88 & 99.76 & 120.06 & 130.13 & 112.64 & 111.85 \\
\hline Supermill (12 ton $\left.\mathrm{ha}^{-1}\right)$ & 68.35 & 93.00 & 153.36 & 166.01 & 239.99 & 197.93 & 204.76 \\
\hline Sebok $\left(12\right.$ ton $\left.\mathrm{ha}^{-1}\right)$ & 73.71 & 91.02 & 91.50 & 91.05 & 103.39 & 97.03 & 94.02 \\
\hline Sufola (12 ton $\left.\mathrm{ha}^{-1}\right)$ & 61.96 & 65.85 & 67.21 & 60.50 & 85.28 & 89.37 & 91.68 \\
\hline $\mathrm{N}_{5} \mathrm{P}_{3} \mathrm{~K}_{3} \mathrm{~kg} \mathrm{ha}^{-1}$ & 28.64 & 77.91 & 81.25 & 60.00 & 53.38 & 53.23 & 117.80 \\
\hline LSD at $5 \%$ level & 0.61 & 0.61 & 0.61 & 0.61 & 0.61 & 0.61 & 0.61 \\
\hline
\end{tabular}

Brady and Weil (2002) concluded that the organic manures contain a passive fraction of 60 to 90 percent which is very slowly available to plants. Therefore, it might be possible that some of the manures contained comparatively larger portion of passive fraction and it took a long time to release nutrients and make them available to plants. 
Besides, various environmental factors, viz. temperature, light intensity, humidity, microbes and supply of nutrient elements also affect the rate of absorption and translocation of nutrients to influence the plant growth (Tisdale et al. 1995). Again, number of leaves and leaf area were recorded comparatively lower in inorganic treatments than control. It can be assumed that inorganic fertilizers did not work well for Mahogany. Doses can be inappropriate as well. It was found that the combined application of organic manure, NPK were better performer for leaf number and leaf area (cm sq.) enhancement of arum (Uddin et al. 2018).

Table 4. Effects of organic manures and NPK fertilizers on the number of branches/plant and girth (cm) of Swietenia mahagoni L.

\begin{tabular}{|c|c|c|c|c|c|c|}
\hline \multirow{2}{*}{ Treatments } & \multicolumn{3}{|c|}{ No. of branches/ plant } & \multicolumn{3}{|c|}{ Girth $(\mathrm{cm})$} \\
\hline & 75d & 90d & 105d & 75d & 90d & 105d \\
\hline Control OM\&- NPK) & 3.67 & 5.67 & 5.67 & 2.44 & 2.49 & 2.53 \\
\hline Kazi and kazi ( 12 ton $\left.\mathrm{ha}^{-1}\right)$ & 0.67 & 1.33 & 3.33 & 2.43 & 2.51 & 2.57 \\
\hline $\mathrm{ACI}\left(12\right.$ ton $\left.\mathrm{ha}^{-1}\right)$ & 1.33 & 2.00 & 3.67 & 2.09 & 2.16 & 2.26 \\
\hline Payel (12 ton ha $\left.^{-1}\right)$ & 2.00 & 3.33 & 6.33 & 2.78 & 2.88 & 2.93 \\
\hline BGF-1(12 ton $\left.\mathrm{ha}^{-1}\right)$ & 1.33 & 0.67 & 3.33 & 2.51 & 2.57 & 2.60 \\
\hline $\operatorname{Mazim}\left(12\right.$ ton $\left.\mathrm{ha}^{-1}\right)$ & 1.67 & 3.67 & 4.00 & 2.53 & 2.60 & 2.73 \\
\hline SK $\left(12\right.$ ton $\left.\mathrm{ha}^{-1}\right)$ & 0.67 & 2.00 & 4.67 & 2.14 & 2.16 & 2.20 \\
\hline Supermill $\left(12\right.$ ton $\left.\mathrm{ha}^{-1}\right)$ & 2.67 & 4.33 & 5.33 & 2.93 & 3.01 & 3.06 \\
\hline Sebok $\left(12\right.$ ton $\left.\mathrm{ha}^{-1}\right)$ & 1.67 & 2.00 & 3.00 & 2.25 & 2.28 & 2.33 \\
\hline Sufola $\left(12\right.$ ton $\left.\mathrm{ha}^{-1}\right)$ & 2.33 & 2.33 & 3.33 & 2.39 & 2.42 & 2.46 \\
\hline $\mathrm{N}_{5} \mathrm{P}_{3} \mathrm{~K}_{3} \mathrm{~kg} \mathrm{ha}^{-1}$ & 1.33 & 2.67 & 4.67 & 2.17 & 2.24 & 2.30 \\
\hline LSD at $5 \%$ level & 3.10 & 3.26 & 2.90 & NS & NS & NS \\
\hline
\end{tabular}

The results of the branch number per plant and the girth of the stem measured from $2 \mathrm{~cm}$ above the soil surface at 105 days before harvesting are presented in Table 4. Branch number was the highest (6.33 no./plant) with the application of Payel. The minimum values for branch number per plant were obtained in the treatment of Sebok (3 no./plant). Branch number (average) per plant varied significantly $(\mathrm{p} \leq 0.5)$ after 60 days up to 105 days (Table 4). The results of the girth value of the stem presented in Table 4. The girth value was maximum $(3.067 \mathrm{~cm})$ in Supermill. The girth values varied significantly $(\mathrm{p} \leq 0.5)$. The minimum value $(2.200 \mathrm{~cm})$ of the girth of the stem was recorded in SK treatment.

\section{Fresh and dry weight plant ${ }^{-1}$}

The yields of fresh and dry weights of leaf, stem and root are presented in Table 5. The highest yields were achieved due to application of Supermill. The total fresh yields in the eleven treatments including the control were 25.17, 20.75, 23.80, 33.28, 20.01, 28.47, 19.82, 37.79, 21.29, 18.62 and 22.50 $\mathrm{g} /$ plant, respectively and the dry weight values in the similar treatments were $12.76,8.12,10.79,15.10$, 7.52, 14.71, 8.25, 18.83, 7.32, 5.72, $7.11 \mathrm{~g} /$ plant, respectively after harvest (Table 5). The maximum total yields of the fresh and dry weights were 37.79 and $18.83 \mathrm{~g} / \mathrm{plant}$.

The values for fresh weights of leaf, stem, and root varied significantly $(p \leq 0.5)$, but the values for dry weights of leaf and stem did not vary significantly (Table 5). The results revealed that the most effective manure was Supermill compost so far growth performance and biomass production of $S$. mahagoni is concerned. 
Table 5. Effects of organic manures and NPK fertilizers on the fresh weight (g/plant) and dry weight (g/plant) of Swietenia mahagoni L.

\begin{tabular}{|c|c|c|c|c|c|c|c|c|}
\hline \multirow[t]{2}{*}{ Treatments } & \multicolumn{4}{|c|}{ Fresh weight(g/plant) } & \multicolumn{4}{|c|}{ Dry weight (g/plant) } \\
\hline & Leaf & Stem & Root & Total & Leaf & Stem & Root & Total \\
\hline Control (-OM\&- NPK) & 14.67 & 5.38 & 5.12 & 25.17 & 7.13 & 2.91 & 2.72 & 12.76 \\
\hline Kazi and kazi (12 ton ha $\left.{ }^{-1}\right)$ & 13.00 & 3.75 & 4.00 & 20.75 & 5.23 & 1.35 & 1.54 & 8.12 \\
\hline ACI (12 ton ha $\left.{ }^{-1}\right)$ & 13.67 & 6.14 & 3.99 & 23.80 & 5.52 & 3.72 & 1.55 & 10.79 \\
\hline Payel $\left(12\right.$ ton $\left.\mathrm{ha}^{-1}\right)$ & 21.67 & 6.15 & 5.46 & 33.28 & 8.29 & 3.75 & 3.06 & 15.10 \\
\hline BGF-1(12 ton ha $\left.{ }^{-1}\right)$ & 12.67 & 4.26 & 3.08 & 20.01 & 5.04 & 1.84 & 0.64 & 7.52 \\
\hline $\operatorname{Mazim}\left(12\right.$ ton $\left.\mathrm{ha}^{-1}\right)$ & 15.67 & 6.64 & 6.16 & 28.47 & 6.47 & 4.42 & 3.82 & 14.71 \\
\hline SK $\left(12\right.$ ton $\left.\mathrm{ha}^{-1}\right)$ & 11.67 & 4.58 & 3.57 & 19.82 & 4.95 & 2.18 & 1.12 & 8.25 \\
\hline Supermill $\left(12\right.$ ton $\left.\mathrm{ha}^{-1}\right)$ & 23.33 & 5.36 & 9.10 & 37.79 & 9.16 & 2.95 & 6.72 & 18.83 \\
\hline Sebok $\left(12\right.$ ton $\left.\mathrm{ha}^{-1}\right)$ & 14.67 & 3.54 & 3.08 & 21.29 & 5.56 & 1.11 & 0.65 & 7.32 \\
\hline Sufola $\left(12\right.$ ton $\left.\mathrm{ha}^{-1}\right)$ & 12.33 & 3.10 & 3.19 & 18.62 & 4.22 & 0.72 & 0.78 & 5.72 \\
\hline $\mathrm{N}_{5} \mathrm{P}_{3} \mathrm{~K}_{3} \mathrm{~kg} \mathrm{ha}^{-1}$ & 15.33 & 3.68 & 3.50 & 22.50 & 4.73 & 1.28 & 1.10 & 7.11 \\
\hline LSD at $5 \%$ level & 4.90 & 4.27 & 2.44 & - & NS & NS & NS & - \\
\hline
\end{tabular}

Length of petiole was noticed in a significant size and also measured from 0 day up to 105 days. Unlike other plants petiole length was literally differentiable. The maximum value of petiole was measured $6.33 \mathrm{~cm}$ for treatment of Supermill. And the lowest value was measured $1.77 \mathrm{~cm}$ for Kazi and kazi (Table 6). The values of petiole length varied significantly $(\mathrm{p} \leq 0.5)$. The petiole length seems to be important in the maturing process and also it will increase the biomass as well as potential value of woods.

Table 6. Effects of organic manures and NPK fertilizers on the length of petiole (cm) of Swietenia mahagoni L.

\begin{tabular}{|c|c|c|c|c|c|c|c|}
\hline \multirow[t]{2}{*}{ Treatments } & \multicolumn{7}{|c|}{ Days after transplanting } \\
\hline & $15 d$ & 30d & $45 d$ & 60d & $75 d$ & 90d & $\overline{105 d}$ \\
\hline Control (-OM\&- NPK) & 2.17 & 3.50 & 4.00 & 5.00 & 4.00 & 4.33 & 5.00 \\
\hline Kazi and kazi (12 ton $\left.\mathrm{ha}^{-1}\right)$ & 2.33 & 3.00 & 3.00 & 3.56 & 3.83 & 4.83 & 1.77 \\
\hline ACI (12 ton $\left.\mathrm{ha}^{-1}\right)$ & 2.00 & 2.50 & 3.50 & 3.83 & 3.50 & 3.83 & 3.83 \\
\hline Payel (12 ton ha $\left.{ }^{-1}\right)$ & 3.00 & 2.83 & 3.83 & 4.00 & 4.67 & 6.33 & 6.17 \\
\hline BGF-1(12 ton ha $\left.{ }^{-1}\right)$ & 2.17 & 2.83 & 3.00 & 4.57 & 3.17 & 3.67 & 4.50 \\
\hline $\operatorname{Mazim}\left(12\right.$ ton $\left.\mathrm{ha}^{-1}\right)$ & 2.00 & 3.00 & 3.67 & 3.90 & 6.17 & 6.33 & 6.17 \\
\hline SK (12 ton $\left.\mathrm{ha}^{-1}\right)$ & 2.00 & 3.17 & 3.33 & 3.97 & 3.10 & 4.00 & 3.67 \\
\hline Supermill $\left(12\right.$ ton $\left.\mathrm{ha}^{-1}\right)$ & 2.67 & 3.00 & 4.83 & 5.33 & 6.17 & 5.50 & 6.33 \\
\hline Sebok (12 ton $\left.\mathrm{ha}^{-1}\right)$ & 2.43 & 3.00 & 3.00 & 2.83 & 3.83 & 4.40 & 4.67 \\
\hline Sufola (12 ton ha-1) & 2.00 & 2.67 & 2.83 & 3.00 & 3.67 & 4.90 & 2.67 \\
\hline $\mathrm{N}_{5} \mathrm{P}_{3} \mathrm{~K}_{3} \mathrm{~kg} \mathrm{ha}^{-1}$ & 1.13 & 2.50 & 2.67 & 2.40 & 3.17 & 3.17 & 4.50 \\
\hline LSD at $5 \%$ level & 2.48 & 3.02 & 3.03 & 1.83 & 3.98 & 3.98 & 4.31 \\
\hline
\end{tabular}

The concentration of $\mathrm{N}$ in the leaf was measured following the method of Cresser and Parsons (1969). The values were 1.3, 1.8, 1.9, 1.9, 1.6, 1.7, 1.4, 1.8, 2.0, 1.8 and 1.4\% in control, Kazi and Kazi, ACI, Payel, BGF-1, Mazim, SK, Supermill, Sebok, Sufola and N5P3K3 kg ha ${ }^{-1}$ respectively. The highest concentration of $\mathrm{N}(2 \%)$ was observed in Sebok treatment and the minimum concentration was noticed at control. The values of $\mathrm{N}$ concentration in leaf did not vary significantly.

Supermill compost is rich in nitrogen $(1.5 \%)$, phosphorus $(0.55 \%)$ and potassium $(0.95 \%)$. Nitrogen is the most imperative element for proper growth and development of plants which significantly increases the yield and its quality by playing vital role in biochemical and physiological functions of plant (Leghari et al. 2016). It may be said that mahogany seedlings should be raised under organic farming system and better growth of the seedlings was achieved in Supermill organic manure. 
The study indicates the application of organic manures in the field can significantly accelerate better growth in mahogany than chemical fertilizers.

\section{REFERENCES}

Alauddin, M., A. H. M. Z. Ali, and M. K. Rahman. 2019. Influence of vermicompost and chemical fertilizers on growth and yield performance of sunflower (Helianthus annus L.). J. Physiol. Ecol. Environ. Sci. 10(1\&2): 25-34.

Bouyoucos, G. T. 1962. Hydrometer method improved for making particle size analysis of soils. Agron. J. 54: 461-465.

Brady, N. C. and R. R. Weil. 2002. The Nature and Properties of Soils. 13th ed. Pearson Education Pte. Ltd., Singapore. $960 \mathrm{pp}$.

Cresser and Parson. 1979. Sulphuric - Perchloric acid digestion of plant material for the determination of Nitrogen, Phosphorus, Potassium, Calcium and magnesium. Anal. Chem. Acta. 109: 431-436.

Hossain, M. K. 2015. Silviculture of plantation trees of Bangladesh. Arannayk Foundation. Dhaka, Bangladesh. 361 pp.

Leghari, S. J., N. A. Wahocho, G. M. Laghari, G. M. Bhabhan, K. H. Talpur, T. A. Bhutto, S. A. Wahocho and A. A. Lashari. 2016. Role of nitrogen for plant growth and development: A review. Adv. Environ. Biol. 10(9): 209-218.

Mader, P., A. Fliessbach, D. Dubois, L. Gunst, P. Fried and U. Niggli. 2002. Soil fertility and biodiversity in organic farming. Science. 296: 1694-1697.

Marr, I. L. and M. S. Cresser. 1983. The lithosphere. Environmental Chemical Analysis. Blackie and Son, UK., pp. 155-182.

Murphy, J. and J. P. Riley. 1962. A modified single solution method for the determination of phosphate in natural waters. Anal. Chem. Acta. 27: 31-36

Orwa, C., A. Mutua, R. Kindt, R. Jamnadass and S. Anthony. 2009. Swietenia mahagoni. Agroforestree Database: Tree Reference and Selection Guide Version 4.0.

Patel, V. B., S. K. Singh, R. Asrey and Y. K. Sharma. 2005. Response of organic manures and biofertilizer on growth, fruit yield and quality of mango cv. Amrapali under high density orcharding. Karnataka J. Horti. 1(3): 51-56.

Tisdale, S. L., W. L. Nelson, J. D. Beaton and J. L. Havlin. 1995. Soil Fertility and Fertilizers. 5th ed. Prentice-Hall of India Private Ltd., New Delhi-110001, India. 634 pp.

Uddin, M. K., J. Sultana, M. Alauddin, M. H. Rahman, M. Akhtar, A. P. Rodrigues, A. H. M. Z. Ali, and M. K. Rahman. 2018. Effects of decomposed poultry litter, nitrogen and phosphorus on growth and micronutrient content of arum (Colocasia esculentus L.). J. Biodivers. Conserve. Bioresour. Manag. 4(1): 11-18.

Walkley, A. and I. A. Black. 1934. An examination of the Degtjareff method for determining soil organic matter and a proposed modification of the chromic acid titration method. Soil Sci. 37: 29- 38.

Watson, C. A., D. Atkinson, P. Gosling, L. R. Jackson and F. W. Rayns. 2002. Managing soil fertility in organic farming systems. Soil Use Manage. 18: 239-247.

Yang, S. M., F. M. Li, D. R. Suo, T. W. Guo, J. G. Wang, B. L. Sun, and S. I. Jin. 2005. Effect of long-term fertilization on soil productivity and nitrate accumulation in Gansu Oasis. Scientia Agricultura Sinica. 38: 2043-2052. 
